\title{
Effects of Chemical, Biological and Botanical for the Management of Alternaria Leaf Spot Disease of Radish for Healthy Seed Production
}

\author{
Subash Gautam ${ }^{1 *}$, Manisha Mahat ${ }^{2}$, Samjhana Khanal ${ }^{3}$ and Hira Kaji \\ Manandhar ${ }^{4}$
}

\author{
${ }^{1,4}$ Department of Plant Pathology, Agriculture and Forestry University, Rampur, Nepal \\ ${ }^{2}$ Nepal Polytechnique Institute, Purbanchal University, Bharatpur, Nepal \\ ${ }^{3}$ Institute of Agriculture and Animal Science, Lamjung Campus, Nepal
}

\begin{abstract}
An experiment was conducted to evaluate the effect of different treatments viz. SAAF (mancozeb + carbendazim) $\left(2 \mathrm{gl}^{-1}\right)$, Acorous calamus root extract (50 $\%)$, Trichoderma harzianum $\left(10^{6}\right.$ conidia $\left.\mathrm{ml}^{-1}\right)$ aqueous suspension and two radish varieties (Mino Early and Pyuthaney Rato) against Alternaria leaf spot disease (Alternaria brassicae) of radish in research plot of Department of Plant Pathology AFU, Chitwan, Nepal during winter season of 2015. Foliar applications of the treatments were used for six times from 40 DAS to 90 DAS at 10 days interval. All treatments were found significant during all observations for per cent disease index (PDI) and yield. Lowest PDI was recorded in application of SAAF (carbendazim 12\% + mancozeb 63\%) (52.33\% and $34.33 \%)$, which was statiscally at par and followed by foliar application of T.harzianum (56.17\% and $39.5 \%)$ in both vegetative growth stage (60 DAS) and reproductive stage (90 DAS) of radish. There was significant difference in PDI between the varieties, Mino Early (43.58 \%) followed by Pyuthaney Rato (49.92\%) in 90 DAS. Similarly in case of seed yield, highest yield was recorded from SAAF (0.6 $t$ hal) followed by Trichoderma harzianum $\left(0.49 \mathrm{th} \mathrm{h}^{-1}\right)$. Also in case of variety significant difference in yield was recorded, highest yield was recorded from Mino Early (0.57 t ha-1) followed by Pyuthaney Rato $\left(0.30 t \mathrm{tha}^{-1}\right)$.
\end{abstract}

Keyword-Acorous calamus, alternaria leaf spot, fungicides, trichoderma.

\section{INTRODUCTION}

Crucifer vegetables are the important winter season cash crop grown in Nepal. Around $70 \%$ of Nepal's total household is involved in vegetable farming (CBS 2010). Radish (Raphanus sativus L.) is one of the top five vegetables produced in Nepal, which covers $7.47 \%$ of total vegetable production area of Nepal with an average productivity of $14.45 \mathrm{mt} \mathrm{ha}^{-1}$ (VDD 2013). Radish crop has easy cultivation practice, wider climatic adaption and extensive use and thus it is popular among the farmers (Shrestha and Shakya 2004). Also, radish is the most important seed crop in terms of high demand of quality commercial seed (HVAP 2011).

The most common and destructive diseases of Brassicaceae crops worldwide are those caused by four species of Alternaria viz., A. brassicae (Berk.) Sacc, A. brassicicola (Schwein.) Wiltsh., A. raphani Groves and Skolko, and A. alternata (Fr.) Keissl which are seed borne pathogen. A. brassicae (Berk.) Sacc, A. brassicicola (Schwein.) Wiltshire are responsible for a serious grey and dark leaf spot disease on those crops (Fazal et al. 1994; Verma and Saharan 1994). At least $20 \%$ of agricultural spoilage is caused by Alternaria species; most severe losses may reach up to $80 \%$ of yield (Shrestha and Chaudhary 1999). Among the root crops like radish, turnip, beet root and carrot, maximum infection (10-60\%) has been found in radish, and the disease has widely spread in all the growing areas of Nepal (Shrestha 1990). Yield reduction up to $45 \%$ in radish has been reported from Kathmandu and Chitwan (Shrestha 1996). Average yield losses in the range of $32-57 \%$ due to Alternaria have been reported from Nepal (Shrestha et al. 2005). Due to high plant parasitic nature of this pathogen it has become major problem in production of seed as it affect most during pod formation stage of the crop affecting seed quality by reducing seed size, seed discoloration and reduction in oil content (Prasad and lallu 2006).

Application of chemical fungicide is the arguably easiest and most effective method for the management of the disease. Chemical fungicide inhibits the spore germination and penetration of the pathogen in host but pathogen can generate resistance against the fungicide if not used in proper dose and interval of time (Namada et al. 2004; Kirik et al. 2005) and cause environmental pollution (Tisdale et al. 1985). These kinds of health and 
environment issues have created deception and fear mongering situation towards the use of chemical pesticides and thus there are strict rules and regulation towards the judicial use of pesticide around the globe. Thus, this study was mainly focused on identifying the effect of different varieties of radish, botanical extract and bio-control agent and chemical fungicide for the management of Alternaria leaf spot of radish and quality seed production.

\section{MATERIALS AND METHODS}

\section{Preparation of the treatments}

Trichoderma selective media was used for isolation of Trichoderma sp. from soil brought from the nearby forest in Rampur, Chitwan (Elad et al. 1981). Morphological observations were made from cultures grown on PDA plates at $24^{\circ} \mathrm{C}$ under ambient laboratory conditions of diffuse daylight. The microscopic characteristics were observed for the more complex conidiophores developing from the characteristic tufted or postulate areas of condition, usually 3 to 5 days after inoculation. Identifications were performed by using the identification keys provided by Rifai 1969 and Bissett 1984, 1991a, 1991b. Examination of the shape, size, arrangement and development of conidiophores or phialides were done and hence identified as Trichoderma harzianum. Concentration of $10^{6}$ conidia $\mathrm{ml}^{-1}$ water was prepared from freshly grown Trichoderma harzianum isolates using haemocytometer. Chemical fungicide SAAF (carbendazim 12\% + mancozeb $63 \%) @ 2 \mathrm{~g} \mathrm{l}^{-1}$ water was prepared for. Fresh roots of Acorus calamus (sweet flag) from healthy plants were collected, surface sterilized for $2 \mathrm{~min}$ in $70 \%$ ethanol, and washed in three changes of distilled water. 100 gram of root sample was weighed and grinded with mortar and pestle and finally paste was filtered in sterile double layered muslin cloth. The volume of filtrate collected was later mixed with $100 \mathrm{ml}$ sterilized distilled water to make stock solution, later it was made $50 \%$ by adding more sterilized distilled water (stock solution: sterilized distilled water as 1:1 proportion). Foliar application of all these treatments was done at 40 DAS for 6 times at 10 days interval. First application was done 40 days after planting.

Table.1: Details of treatments combination

\begin{tabular}{lll}
\hline SN & Treatment combination & Concentration \\
\hline 1 & Mino Early + SAAF & $2 \mathrm{gl}^{-1}$ \\
2 & Mino Early + Acorus calamus root extract & $50 \%$ ( 1part root extract in 2 part \\
& & distilled water) \\
3 & Mino Early + Trichoderma harzianum & $10^{6}{\text { conidia } \mathrm{ml}^{-1}}$ \\
4 & Mino Early + control (distilled water) & - \\
5 & Pyuthane Rato + SAAF & $2 \mathrm{~g} \mathrm{l}^{-1}$ \\
6 & Pyuthane Rato + Acorus calamus root extract & $50 \%$ \\
7 & Pyuthane Rato + Trichoderma harzianum & $10^{6}{\text { conidia } \mathrm{ml}^{-1}}^{-1}$ \\
\hline
\end{tabular}

\section{Disease incidence and Severity}

Observation of disease was done from ten sample plants randomly selected and tagged for further observations. First scoring was done 40 days after sowing (DAS), respectively; two more scoring at an interval of 10 days were done for foliar severity assessment. Similarly, first stem and pod disease scoring was done at 70 DAS and

$$
\text { Percent disease index }(\mathrm{PDI})=\frac{\text { sum of all ratings }}{\text { total number of plants observed } \times \text { maximum disease rating scale }} \times 100
$$

\section{RESULTS AND DISCUSSIONS}

Disease severity of Alternaria leaf spot at 40, 50, 60, 70, 80 and 90 DAS of radish varied significantly among the treatments and also between the two varieties except for 60 DAS. At 40 DAS lowest percent disease index (PDI) was recorded in application of SAAF (35.00\%) which was followed by foliar application of Trichoderma harzianum (46.50\%). At 50 DAS lowest percent disease other two scoring was done at an interval 10 days. Disease scoring was done in $0-5$ scale $(0=$ no infection, $1=1-5 \%$ infection, $2=6-10 \%$ infection, $3=11-20 \%$ infection, $4=21-30 \%$ infection, $5=31-100 \%$ infection (Shrestha et al. 2005). The disease severity of foliar and stem and pods diseases at each disease scoring was calculated using the formulae (Ayyanagar 1928).

index (PDI) was recorded in application of SAAF $(51.83 \%)$ which is statically at par with foliar application of Trichoderma harzianum (55.50\%). At 60 DAS lowest percent disease index (PDI) was recorded in application of SAAF $(52.33 \%)$ which was statically at par with foliar application of Trichoderma harzianum (56.17\%). Similarly in case of varieties during vegetative stage, at 40 and 50 DAS lowest percent disease index (PDI) was 
recorded in Mino early (43.20\% and 53.42\%) followed by Pyuthaney Rato (53.42\% and $60.25 \%$ ) whereas at 60 DAS there was not any significant difference between the varieties.

There was abrupt decline in PDI in all treatments including untreated control due to defoliation of the plant. Soon after that severity percentage increased with the development of the reproductive part of the plants. At 70, 80 and 90 DAS lowest percent disease index (PDI) was recorded in application of SAAF $(21.33 \%, 25.17 \%$ and $34.33 \%$ ) which was followed by foliar application of Trichoderma harzianum $(27.50 \%, 33.67 \%$ and $39.50 \%)$ respectively. Similarly in case of varieties, at 70, 80 and 90 DAS lowest percent disease index (PDI) was recorded in Mino Early $(24.50 \%, 33.00 \%$ and $43.58 \%)$ followed by Pyuthaney Rato (33.75\%, $43.60 \%$ and $49.92 \%)$ respectively.

Highest yield was recorded from SAAF (0.6 $\left.\mathrm{t} \mathrm{ha}^{-1}\right)$ followed by Trichoderma harizanum foliar application $\left(0.49 \mathrm{tha}^{-1}\right)$ at $90 \mathrm{DAS}$. And in case of variety also the significant difference in yield was recorded, highest yield was recorded from Mino Early $\left(0.57 \mathrm{t} \mathrm{ha}^{-1}\right)$ and lowest from Pyuthaney Rato $\left(0.30 \mathrm{t} \mathrm{ha}^{-1}\right)$ at 90 DAS.

Table.2: Effect of foliar spray on the severity of Alternaria leaf spot of radish in Horticulture farm at AFU, Rampur, Chitwan during 2014-2015

\begin{tabular}{|c|c|c|c|c|c|c|c|}
\hline \multirow[t]{2}{*}{ Factors } & \multicolumn{2}{|c|}{$\begin{array}{l}\text { PDI at Vegetative } \\
\text { formation ) }\end{array}$} & \multirow{2}{*}{$\begin{array}{c}\text { Stage (Leaf } \\
60 \text { DAS }\end{array}$} & \multicolumn{3}{|c|}{$\begin{array}{l}\text { PDI at Reproductive stage (Pod and } \\
\text { Stem formation) }\end{array}$} & \multirow[t]{2}{*}{$\begin{array}{l}\text { Yield }(\mathrm{t} \\
\left.\mathrm{ha}^{-1}\right)\end{array}$} \\
\hline & 40 DAS & 50 DAS & & 70 DAS & 80 DAS & 90 DAS & \\
\hline \multicolumn{8}{|l|}{ Variety } \\
\hline Mino Early & 43.20 & 53.42 & 57.50 & 24.50 & 33.00 & 43.58 & 0.57 \\
\hline Pyuthaney Rato & 50.10 & 60.25 & 62.20 & 33.75 & 43.60 & 49.92 & 0.30 \\
\hline LSD value at $\alpha 0.05$ & 6.51 & 3.32 & Ns & 3.43 & 5.22 & 3.16 & 0.06 \\
\hline SEM value \pm & 2.15 & 1.09 & 1.66 & 1.13 & 1.72 & 1.04 & 0.02 \\
\hline \multicolumn{8}{|l|}{ Treatments } \\
\hline SAAF@ @ gm lit ${ }^{-1}$ & $35.00^{\mathrm{c}}$ & $51.83^{\mathrm{c}}$ & $52.33^{\mathrm{c}}$ & $21.33^{\mathrm{c}}$ & $25.17^{\mathrm{d}}$ & $34.33^{\mathrm{d}}$ & $0.60 \mathrm{a}$ \\
\hline $\begin{array}{l}\text { Acorous calamus root extract } \\
\text { @ } 50 \%\end{array}$ & $47.83^{\mathrm{b}}$ & $58.00^{\mathrm{ab}}$ & $61.33^{\mathrm{b}}$ & $29.17^{\mathrm{b}}$ & $42.67^{\mathrm{b}}$ & $46.50^{\mathrm{b}}$ & $0.39 \mathrm{c}$ \\
\hline $\begin{array}{l}\text { Trichoderma harzianum @ } 10^{6} \\
\text { conidia } \mathrm{ml}^{-1}\end{array}$ & $46.50^{c}$ & $55.50^{\mathrm{bc}}$ & $56.17^{\mathrm{bc}}$ & $27.50^{\mathrm{b}}$ & $33.67^{\mathrm{c}}$ & $39.50^{c}$ & $0.49 b$ \\
\hline Control & $57.33^{\mathrm{a}}$ & $62.00^{\mathrm{a}}$ & $69.67^{\mathrm{a}}$ & $38.50^{\mathrm{a}}$ & $51.67^{\mathrm{a}}$ & $66.67^{\mathrm{a}}$ & $0.26 \mathrm{~d}$ \\
\hline $\operatorname{LSD}(=0.05)$ & 9.21 & 4.69 & 7.12 & 4.85 & 7.39 & 4.48 & 0.08 \\
\hline $\operatorname{SEm}( \pm)$ & 3.04 & 1.54 & 2.35 & 2.26 & 2.44 & 1.47 & 0.02 \\
\hline Coefficient of variation (\%) & 15.94 & 6.67 & 9.60 & 13.45 & 15.58 & 7.70 & 16.15 \\
\hline Grand mean & 46.7 & 56.83 & 59.90 & 29.12 & 38.29 & 46.75 & 0.43 \\
\hline
\end{tabular}

Figures in column with same letter are not significantly different $(\mathrm{p}=0.05)$. LSD= Least significant difference. $\mathrm{SEm}=$ standard error of mean

In present study among the fungicide, biocontrol agent and botanical, SAAF @ $0.2 \mathrm{~g} \mathrm{1^{-1 }}$ was most effective followed by foliar application of Trichoderma harzianum @ $10^{6}$ conidia $\mathrm{ml}^{-1}$ and foliar application of Acorous calamus root extract @ 50\% in reducing PDI of alternaria leaf spot disease and increasing the seed yield. The finding of this study was similar to the findings of Ansari et al. (1990) where the best control of alternaria blight was from the foliar application of mancozeb based fungicide viz. Dithane M 45. Furthermore, Arifuzzaman et al. (2007) reported spray of Mancozeb (0.3\%) and carbendazim $(0.1 \%)$ reduced disease severity by $52.27 \%$ and $70.95 \%$ in leaf where as $54.99 \%$ and $78.11 \%$ in pod. The fungi toxic and inhibitory effect of the chemical fungicide SAAF may be the reason behind minimum disease severity. The yield were significantly higher in foliar application of Trichoderma harzianum (Thakur et al. 2017). Mycoparasitic behavior of the Trichoderma sp. is reported to give systemic protection against many seed borne foliar diseases (Hanson 2000) which may be the probable reason behind the lowest disease incidence with the use of Trichoderma harzianum. The disease causes black spots on leaves, stems and pods resulting in the loss of both yield and quality of seed of radish. Incidence of Alternaria blight and its adverse effect on seed yield had been reported by (Meenu and Hundal 2004). Bhandari (2008) reported that $0.2 \%$ Mancozeb spray was the best for controlling the disease and had highest yield $(0.73$ $\mathrm{t} / \mathrm{ha}$ ) which is similar to the findings of present study. The higher yield in SAAF sprayed plot was may be due to 
lower disease severity in SAAF sprayed plot in both vegetative and reproductive stage of radish plant. In case of variety Mino Early was better performing than Pyuthaney Rato, this was may be due smooth leaf surface of the Pyuthane Rato which was favorable for spore germination of the pathogen (Alternaria brassicae) leading to higher disease severity and lower yield of the radish seed.

\section{CONCLUSIONS}

From the present study it is clear that foliar spray of SAAF (mancozeb and carbendazim) @ $2 \mathrm{~g} \mathrm{l}^{-1}$ is the best control measure for controlling alternaria leaf spot of radish and increasing seed yield. However we cannot ignore environmental and health hazards due to the use of chemical fungicide. Foliar application of Trichoderma harzianum@10 $0^{6}$ conidia $\mathrm{ml}^{-1}$ was also found to be significant in reduction of disease and increasing seed yield. In conclusion, foliar spray of Trichoderma harzianum @ $10^{6}$ conidia $\mathrm{ml}^{-1}$ could be used for the control of alternaria leaf spot disease of Radish as it is quite good method of bio-control, affects a wide range of plant pathogens, acts as good mycoparasite, produces antibiotics and has an enzyme system to inhibit growth of pathogen and more importantly ecofriendly. However, further studies on efficacy of different conidial concentration of different Trichoderma isolates can be done for further identification of best concentration of the different isolates.

\section{ACKNOWLEDGEMENT}

The authors are thankful to Agriculture and Forestry University (AFU), Rampur for the support and cooperation during the research.

\section{REFERENCES}

[1] CBS. 2010. Central Bureau of Statics. Nepal Vegetable Crop Survey 2009-10. Thapathali, Kathmandu, Nepal.

[2] VDD. 2014. Vegetable Development Directorate. Annual progress report of the vegetable, potato, and spices development program (in Nepali).Vegetable Development Directorate, Khumaltar, Lalitpur, Nepal. p. 120-130.

[3] Abul-Fazal MOHD, Khan MI, Saxena SK. 1994.The incidence of Alternaria species in different cultivars of cabbage and cauliflower seeds. Indian Phytopathology, 47(4), 419-421.

[4] Ansari NA, Khan MW, Muheet A. 1990. Evaluation of some fungicides for seed treatment and foliar application in management of damping-off of seedlings and blight of rapeseed caused by
Alternaria brassicae. Mycopathologia, 110(3):163167.

[5] Arifuzzaman M, Rashid MM, Hasan MS, Ferdousi MS. 2007. Foliar spray of fungicides to control Alternaria Blight of Radish seed crop. Journal of Science technology (Dinajpur) 5: 140-143.

[6] Ayyangar CR. 1928. A leaf spot and blight diseases caused by Alternaria palandui. Agric Res Inst Pusa Bull, 179: 14.

[7] Bhandari NR. 2008. Management of Alternaria leaf spot and blight of Radish by biological and Botanical extract for seed production in Chitwan [master's thesis]. Rampur (CT): Institute of Agriculture and Animal Science.

[8] Bissett J. 1984. A revision of the genus Trichoderma. I. Section Longibrachiatum sect. nov. Can J Bot. 62:924-931

[9] Bissett J. 1991. A revision of the genus Trichoderma. III. Section Pachybasium. Can J Bot. 69:2373-2417.

[10]Bissett J. 1991. A revision of the genus Trichoderma. IV. Additional notes on section Longibrachiatum. Can J Bot. 69:2418-2420.

[11]Elad Y, Chet I, Henis Y. 1981. A selective medium for improving quantitative isolation of Trichoderma sp. from soil. Phytoparasitica, 9(1), 59-67.).

[12] Hanson LE. 2000. Reduction of verticillium wilt symptoms in cotton following seed treatment with Trichoderma virens. Journal of Cotton Science, 4(4):224-231.

[13]HVAP. 2011. A Report on Value Chain Analysis of Vegetable seeds in Nepal: High Value Agriculture Project in Hill and Mountain Areas; [accessed in 2015 March 20]. http://www.hvap.gov.np

[14] Kirk WW, Abu-El Salem FM, Muhinyuza JB, Hammerschmidt R, Douches DS. 2005 Evaluation of potato late blight management utilizing host plant resistance and reduced rates and frequencies of fungicide applications. Crop Prot, 24: 961-970.

[15] Meenu S, Hundal S. 2004. Effect of different environment on intensity of Alternaria blight on seed yield of radish crop. Journal of Agrometerology, 6(special issue): 129-131.

[16] Namanda S, Olanya OM, Adipala E, Hakiza JJ, ElBedewy R. 2004. Fungicide application and host resistance for potato late blight management: benefits assessment from on-farm studies in S.W. Uganda.Crop Prot, 23: 1075- 1083.

[17] Prasad R, Lallu. 2006. Management of Alternaria blight of mustard with combination of chemicals and botanicals. Ann. Pl. Protec. Sci. 14:2 400- 403.

[18]Rifai MA. 1969. A revision of the genus Trichoderma. Mycol Pap. 116:1-56. 
[19] Shrestha KK. 1990. Major disease of vegetable crops in Nepal (In Nepali). FAO Fresh Vegetable and Seed Production Projects, Vegetable Development Division, Khumaltar, Lalitpur, Nepal.15-22.

[20] Shrestha KK. 1996. Major disease of vegetable crops in Nepal (In Nepali).FAO Fresh Vegetable and Seed Production Projects, Vegetable Development Division, Khumaltar, Lalitpur, Nepal. 122.

[21] Shrestha SK, Munk L, Mathur SB. 2005. Role of weather on Alternaria leaf blight disease and its effect on yield and yield components of mustard. Nepal Agric. Res. J, 6, 62-72.

[22] Thakur Y, Zacharia S, Chauhan BS. 2017. Efficacy of bio-agents and plant extracts against Alternaria leaf blight of mustard (Brassica juncea L.).

[23] Tisdale SL, Nelson WL, Beaton JD. 1985. Soil fertility and fertilizers.Collier Macmillan Publishers.

[24] Verma PR, Saharan GS. 1994. Monograph on Alternaria diseases of crucifers. Minister of Supply and Services, Saskatoon, Canada. 